gene on nicotinic acid content. The data failed, however, to show any clear indication of the yellowwhite difference affecting nicotinic acid content.

An effect of environment is also suggested by the contents of five strains in the two years 1943 and 1944 (see Table 2). In all but Quebec 28, the 1944 content is much below that of 1943 . The difference is not, however, significant ( $P$ between $0 \cdot 20$ and $0 \cdot 10$ ) and so the data cannot be regarded as clear on this point.

Finally we may observe that sweet corn approaches English wheat $(48.0 \mu \mathrm{gm}$. $/ \mathrm{gm}$.) in nicotinic acid content. This in turn is a little poorer than Manitoba wheat $(55 \cdot 0-66 \cdot 0 \mu \mathrm{gm} . / \mathrm{gm}$.), and much poorer than barley $(91 \cdot 5-147 \cdot 0 \mu \mathrm{gm}$./gm.). On the other hand, even starchy maize is higher than oats $(4 \cdot 9-7 \cdot 0$ $\mu \mathrm{gm} . / \mathrm{gm}$.$) and rye (7 \cdot 7-10 \cdot 0 \mu \mathrm{gm} . / \mathrm{gm} .)^{1}$.

' Barton-Wright, E. C., Biochem. J., 38, 314 (1944).

2 Strong, F. M., and Carpenter, L. E., Ind. Eng. Chem., Anal. Ed., 14, 909 (1942).

"Hayes, H. K., and Immer, F. R., "Methods of Plant Breeding" (McGraw-Hill Co., Ltd.; 1942).

\section{SCIENCE AND THE PUBLIC}

" THE Publicity of Science, with particular reference to Chemistry" was considered in relation to the Press, exhibitions, films and broadcasting at a discussion arranged by the London and South Eastern Counties Section, Royal Institute of Chemistry, on October 20.

Dr. O. J. R. Howarth, secretary of the British Association, said that there is an increasing public interest in science, for which neither science nor the Press is as yet making adequate provision. It is probably fair to say that oducation has not yet caught up with the interests of the people. The languages of the sciences are unfamiliar, and men of science do not always realize this. Among them, gifted exponents to the lay public are uncommon; among journalists, those of scientific training sufficient to fit them as scientific correspondents are as yet not numerous. Press news of seience could be improved (with the assent of editors) by qualified writers, either free-lance or as scientific representatives of particular newspapers or agencies. The American Science News Service is a strong and efficient organisation, but it has been asserted, whether justifiably or not, that in Great Britain the field for syndicated news is not wide enough to sustain a separate science news agency. The present time does appear opportune, however, for a practical review of the whole question. How should this be initiated? Probably initiation does not lie with science; but if from the side of the Press there should come a strongly backed request for help in the provision of authoritative scientific news, this ought not to find science unresponsive.

Mr. O. F. Brown, chief information officer of the Department of Scientific and Industrial Research, considered that exhibitions provide the most satisfying form of publicity media. In presenting a scientific exhibition it is essential for the man of science and the display artist to work in full mutual understanding. The exhibits and their component parts must attract attention, hold interest and leave a lasting impression. Stands should be designed to suit exhibits. Dioramas and good photographs are attractive, and lighting devices for fading one object into another have great possibilities for illustrating changes which a substance undergoes. Movement can be introduced effectively into unlikely exhibits. Demonstrations excite interest, but short loops of film projected on to ground-glass screens, and running continuously, may well be used to illustrate laboratory processes.

Exhibitions serve to make new contacts; and it is essential, therefore, that the demonstrator should know his job and possess the right personality. The presentation of an exhibition develops a man's confidence, and as self-confidence is essential to the successful research worker, participation in producing exhibits could be justified for this reason alone.

Mr. George A. Jones, of the Scientific Film Association, emphasized the profound effect which the film, employing the combined effects of motion, colour and sound, can have on the regular cinema-goer; and yet such an individual is ill-informed about science and rarely connects it with the food he eats and the clothes he wears.

The growth of scientific film societies throughout Britain indicates an increasing public demand for information on science. Most of the films available have been designed primarily for training, propaganda or advertising purposes, but fortunately many of the so-called documentary and instructional films have dealt with the relation between science and our daily lives. The instructional films have treated this factually, while the documentaries have been more concerned with interpretation. Many of the latter have exhibited a true scientific outlook. The filmmaker must replace the unscientific and pseudoscientific films by new ones based on a scientific outlook, and produce new films dealing not only with scientific technology but also with the essentials and meaning of science, and its effect upon the modern world. Some films already do this; those in which chemistry is concerned include "D.D.T.", "Enough to Eat", "Malaria", and "Distillation". Interpretative films are also needed to bring home to scientific workers themselves the wider part they play-that they are not only experts on certain technical subjects but also specialists in the logical, detached examination of facts and in making deductions from those facts.

Mr. Vincent Alford, acting assistant director of talks, British Broadcasting Corporation, described the unique advantages of broadcasting as a publicity medium. In addition to reports of scientific progress in the news, science is projected into the radio programme by 'features' and talks. Feature technique calls for the co-operation of scientific workers with producers and the employment of script writers to dramatize aspects of science, actors to impersonate scientific men, and the ancillary aspects of music and effects to heighten the dramatic impression; but there must be no sacrifice of accuracy to dramatic effect. By contrast, a broadcast talk is the unadorned spoken word. Speakers should therefore be selected for their ability to take infinite pains to interpret their subject in a language that at once rouses interest and remains intelligible to the audience. Features and talks are complementary, for while the former have a wider audience, the latter are better for explaining points. Experience shows that it is easier to ensure good broadcasts on physics or biology than on chemistry. Chemistry presupposes the knowledge of a basic vocabulary which is not learned in the elementary school and which cannot be taken for granted. Science broadcasts for schools have been helping to build up a science-conscious generation to follow ours. It may be considered that the ration of 
science in the talks programmes of the B.B.C. is not enough, but in the congested home service schedules, politics, sociology and straight service talks have to compete in a quota above which the listener will not devote attention. At present, "Science Magazine", on the home service every fortnight, and "Science Notebook", in the short-wave overseas service, merit consideration.

Contributions to the discussion came from speakers directly concerned with the scientific and technical Press, films and broadcasting. Among the points made were that scientific men are partly to blame for unsatisfactory reports on scientific matters in the Press because of their dislike of publicity and their attitude to those who try to interpret such matters to the layman. Hence those who can write well should do so. The censorship of scientific news creates a vacuum which tends to fill with unreliable information; rather should the scientific man give an interview and take the reporter into his confidence, but refrain from extensive statements by telephone. The 'pipe-line' connecting the scientific world and the Press is too narrow, scientific information has to pass through several stages of digestion before it is published in the lay Press, and newspaper editors do not appear to realize the existence of the great public interest in scientific matters. The Press should have scientific editors, who should have a wide knowledge of the sciences and adequate contacts to enable them to check scientific news; they should be able to rely on the professional and learned societies for aid. A 1951 Exhibition, already mooted, should be supported by the professional institutes of the sciences. Historical and biographical films of sciences and scientific men should be encouraged; the Ministry of Education and the learned and professional scientific bodies could assist in these productions. The success of "Science Magazine" depends upon the scientific men who write the scripts; only one idea at a time should be transmitted, in a concise manner.

It was suggested by several speakers that groups in local sections of professional bodios, or an informal society or group for people interested in the publicity of science, should be formed to further, by exchange of ideas and experiences, the presentation of science to the public.

\section{ANTHROPOLOGY IN PORTUGAL}

$\mathrm{T}$ history of any branch of science is a very intricate affair as it entails national and international claims of priority, and one is at a loss as to whether the contribution of a particular school is of greater or less significance. The problem is still further complicated when the protagonists are still alive. The history of anthropology in Portugal is worthy of notice by itself, if only because Portugal was one of the great colonial Powers whose influence can still be felt in Brazil, Africa, India and the East Indies.

Pereira da Costa, Carlos Ribeiro and Nery Delgado founded a Geological Society in Lisbon in 1857. In 1865 Pereira da Costa published his "Notices on Human Skeletons discovered in a Cave by Arruda". In 1885, a Ministerial decree authorized the reorganization of museums, and the director asked Barros da Cunha to examine some Timor skulls deposited there. The museum was divided into sections of botany, zoology, geology and mineralogy, anthropology and archæology, each with its own director.
From this time dates the systematic collection of materials from the Portuguese Colonies.

On July 2, 1885, Dom Luiz passed a further decree creating a Department of Anthropology, Human Palæontology and Archæology in the Faculty of Philosophy of the University of Coimbra. Two years previously, Bernard Machado had brought up a Bill creating Departments of Agriculture, Rural Economy, Mines and Zootechnology in the University.

In the earlier phase emphasis was laid on prehistoric archxology, particularly on the existence of tertiary man in Portugal, because of the interest shown in the discovery of da Arruda in the grottoes of Furninha and Cesareda, and the graveyards of the Tejo Valley. In the second phase physical anthropology came to the fore, partly owing to the zeal of Ferraz de Macedo and Arruda Furtado. Macedo began his craniometric studies on the remains found in the old cemeteries of Lisbon in 1882 ; and in the following years he devoted himself to criminal anthropometry with good results. The methods standardized by him have proved useful to subsequent workers in this field.

The first professor of anthropology at the University of Coimbra was Henrique Texeira Bastos, who divided the subject into : (1) zoological and general anthropology and (2) prehistoric archæology. Section I dealt with the osteology and craniometry of primates and physiological differences between them and man. The position of man among the primates was also treated. In osteology, the comparative osteology of man was studied. In this section were included methodology, anthropometry, statistics, etc. Section 2 treated the comparative history of man and human races, cultural anthropology, linguistics and prehistoric archæology. The Faculty of Letters taught ethnology for a semester to those who were graduating in geography, but as a matter of fact the subject received but scant attention.

In 1911, Prof. Barros da Cunha began a free voluntary course on colonial anthropology at the Institute of Anthropology and at the Colonial Museum, the subjects being customs, religion, dress, art, folklore and languages. Soon after, monographs on places of local interest began to be published in the Transactions of the Section of Anthropology of the University of Coimbra.

Bastos was succeeded by Bernard Machado, whose enthusiasm and interest in physical anthropology ushered in a new period of intense activity. The series of monographs published in the Transactions attest his powers of classification and his unusual activities in all branches of science. 'But Machedo's work could not properly come under orthodox anthropology; for one thing, his treatment was too diffuse; and for another, he was interested in too many things at the same time.

Two other names stand out in Portuguese anthropology, namely, Anthony da Costa Ferreira and Ferraz Macedo. The latter may be claimed as the true founder of physical anthropology in Portugal, for his craniometric investigations provided a basis for later workers.

With the reform of the University of Coimbra in 1911, two institutes of anthropology were established, one at Oporto and the other at Lisbon. At the same time, at Coimbra the curriculum was reorganized and anthropology was divided into physical and cultural. The influence of social and climatic factors was actively studied and attention was directed to palæontology; and as an ultimate 